\title{
High-Risk Perioperative Medications in the Chinese Elderly Population
}

\author{
Shuying Wang \\ Weifang Ren \\ Xiaofang Tan \\ Xiaoqun Lv \\ Yujuan Liu \\ Yuan Gong
}

Department of Pharmacy, Jinshan Hospital of Fudan University, Shanghai, People's Republic of China
Correspondence: Yuan Gong

Department of Pharmacy, Jinshan Hospital

of Fudan University, No. 1508, Road

Longhang, Shanghai, 20I508, People's

Republic of China

Email gongyuan@alumni.sjtu.edu.cn
Background: Inappropriate perioperative medications among elderly patients increase the risk of adverse events and undermine surgical outcomes. This study aimed to assess the prevalence of high-risk medications in elderly surgical patients and verify the effectiveness of a new-developed high-risk perioperative medications (HRPOMs) list for the elderly.

Methods: A cross-sectional, single-center study was conducted at Jinshan Hospital of Fudan University. A total of 810 elderly surgical patients were included in the study. The HRPOMs list was applied to patients' data to identify the HRPOMs including chronic medications and medications related to surgery.

Results: A total of 2113 HRPOMs were identified in 810 patients who fulfilled the inclusion criteria. Of these, 1067 (50.5\%) involved medications related to surgery, and 982 (46.5\%) involved chronic medications. The prevalence of HRPOM exposure, which was defined as at least one HRPOM was $76.3 \%$. Patients that were 70 years or older (adjusted odds ratio $[\mathrm{AOR}]=2.118,95 \%$ confidence interval $[\mathrm{CI}], 1.420 \sim 3.159)$, hospitalized over two weeks $(\mathrm{AOR}=4.192,95 \% \mathrm{CI}, 1.493 \sim 11.771)$, with more than 2 distinct diagnoses $(\mathrm{AOR}=3.407$, 95\% CI, 2.224 5.220) and with 16 or more medications during hospitalization were more likely to be exposed to HRPOMs. Patients who underwent surgeries of Grade IV were at 1.73 increased odds of HRPOM exposure compared with those who received surgeries of Grade III or lower $(\mathrm{P}=0.071)$.

Conclusion: HRPOMs are more common in patients of 70 years or older, with 3 or more distinct diagnoses, with 16 or more medications and hospitalized for 15 days or longer. Our study showed the validity of the HRPOMs list in the perioperative medication review for the elderly and may induce further research to reveal the impact of HRPOMs upon the surgical outcomes of the elderly.

Keywords: prevalence, high-risk perioperative medication, elderly, China

\section{Introduction}

With the progress of medical technology, an ever-increasing number of operative procedures are performed in patients, especially in aged patients. Compared with their younger counterparts, the older surgical patients encounter a higher risk of perioperative complications and mortality due to deteriorated physical function and surgical stress. ${ }^{1,2}$ Additionally, the elderly are susceptible to multiple comorbid conditions and have to take chronic medications. The inappropriate withdrawal or withholding of chronic medications in perioperative period is associated with an increased risk for drug-related problems (DRPs), including medication errors and adverse events. ${ }^{3,4}$ Also, the adverse interactions between chronic medications and medications related to surgeries, for instance, anesthetics, analgesics, antibiotics 
and contrast agents, jeopardize surgical outcomes for the aged patients. ${ }^{5}$ For these reasons, it is necessary to review the perioperative medications for the elderly all along the care pathway to identify drugs that potentially imperil the safety of the patients.

A medication review refers to the structured evaluation of a patient's medication regime to provide convenience in minimizing the number of the DRPs and optimizing the patients' outcomes. A few published studies have established tools for reviewing the elderly patients' medication regimes and optimizing the patients' pharmacotherapy. Most of these tools are based on explicit criteria, including the Beers criteria, ${ }^{6}$ The Screening Tool for Older Person's Prescription (STOPP) and Screening Tool to Alert doctors to Right Treatment (START) criteria, ${ }^{7}$ Priscus List, ${ }^{8}$ Australian Prescribing Indicators Tool, ${ }^{9}$ French Consensus Panel List, ${ }^{10}$ Zhan's criteria ${ }^{11}$ and Improved criteria in the elderly tool. ${ }^{12}$ These criteria were mostly used to assess the elder medical patients' medication rather than surgical ones', for they failed to evaluate the interactions between medications and perioperative physical and pathological conditions as well as interactions between chronic medications and surgery-related medications. Whereas, a few clinical studies have researched the chronic medication withdrawal and withholding in the perioperative period. ${ }^{13-20}$ These preexisting studies focused on the impact of specific medication categories upon surgical patients yet did not provide an explicit evidence-based medication list to guide prescribing and medication audit.

Under the circumstances, Chinese experts have developed an explicit criterion as the tool for reviewing highrisk perioperative medications (HRPOMs) for the elderly. ${ }^{21}$ The HRPOMs are defined as (i) drugs that easily cause toxicity or adverse reactions due to aging physical function and surgical stress, (ii) drugs whose inappropriate withdrawal or continuation in the perioperative period easily causes more harm than benefit, (iii) drugs that can be replaced with safer alternatives. A few previous studies have demonstrated that HRPOMs can undermine the physical function or worsen the pathological conditions, ${ }^{13,22}$ postpone or exacerbate the recovery of the surgical wound, ${ }^{15,23}$ and impair the treatment of surgical complications. $^{20}$

Whereas, there was no literature verifying the HRPOM list, and assessing the prevalence of HRPOMs for the elderly so far. This cross-sectional study aimed to screen the HRPOMs and the association between HRPOM exposure and the demographic and clinical characteristics of the older patients admitted to a Chinese universityaffiliated general hospital, and verify the effectiveness of the new-developed HRPOM list.

\section{Methods}

The study population comprised consecutive admissions to the surgical wards of a general hospital over a 6-month period (January 2020-June 2020). All patients aged $\geq 65$ years were eligible for inclusion. The medication list for each patient included medications prescribed after the admission and drugs, which were taken before the admission for chronic diseases. The solvents and traditional Chinese medicines were excluded. Demographics and clinical characteristics were obtained using the Hospital Information System, included patient demographics, the number of diagnoses at discharge, day of hospital stay and the magnitude of the surgery. As some patients were admitted more than once to the hospital during the study period, calculations were based on admissions rather than patients. Screening for HRPOMs for the elderly was performed with the Microsoft Excel Visual Basic for Applications and was manually reviewed by 2 clinical pharmacists (Ren and Tan).

Chi-square analysis was used for univariate analysis and multivariate logistic regression analysis was used to establish the association between HRPOM exposure, which is defined as at least one HRPOM, and both demographic and clinical variables (expressed as odds ratio with 95\% confidence intervals, [CI]). Statistical analysis was conducted using the SPSS software package version 25 (SPSS, Chicago, IL). Figures were drawn using the GraphPad Prism version 9.00 for Windows, GraphPad Software, San Diego, California, USA.

An ethics committee review was not required as the study was a clinical audit, and the patient data was anonymized to comply with relevant data protection and privacy regulations.

\section{Results}

Between January 1st 2020 and June 30th 2020, 810 patients were admitted to Jinshan Hospital of Fudan University to undergo surgery. All patients were included in the study and $618(76.3 \%)$ of them encountered HRPOM exposure. In total, 19,224 medications including chronic medications and medications prescribed after the admission were used by the 810 patients, and 2113 HRPOMs were identified (11.0\%). 
Table I Demographics and Clinical Characteristics of the Study Population in Jinshan Hospital of Fudan University, Shanghai, China, Between Jan Ist and June 30th, 2020

\begin{tabular}{|c|c|c|}
\hline $\begin{array}{l}\text { Patient Characteristics } \\
\text { and Clinical Data }\end{array}$ & $\mathbf{N}(\%)$ & HRPOMs(\%) \\
\hline \multicolumn{3}{|l|}{ Sex, n (\%) } \\
\hline Female & $399(49.3)$ & $273(48.2)$ \\
\hline Male & $4 I I(50.7)$ & $293(51.8)$ \\
\hline \multicolumn{3}{|l|}{ Age } \\
\hline $65 \sim 69$ & $296(36.5)$ & I9I (30.9) \\
\hline$\geq 70$ & $514(63.5)$ & $427(69.1)$ \\
\hline \multicolumn{3}{|l|}{ Number of distinct diagnosis } \\
\hline $1 \sim 2$ & $233(28.8)$ & $120(19.4)$ \\
\hline $3 \sim 5$ & $356(43.9)$ & $296(47.9)$ \\
\hline$\geq 6$ & $221(27.3)$ & $202(32.7)$ \\
\hline \multicolumn{3}{|l|}{ Days of hospital stay } \\
\hline$\leq 7$ & $423(52.2)$ & $263(42.6)$ \\
\hline $8 \sim 14$ & $221(27.3)$ & $194(31.4)$ \\
\hline$\geq 15$ & $166(20.5)$ & $161(26.1)$ \\
\hline \multicolumn{3}{|l|}{ Number of medications } \\
\hline$\leq 15$ & $219(27.0)$ & $97(15.7)$ \\
\hline $16 \sim 24$ & $286(35.3)$ & $229(37.1)$ \\
\hline$\geq 25$ & $305(37.7)$ & $292(47.2)$ \\
\hline \multicolumn{3}{|l|}{ Grade of surgeries } \\
\hline Surgeries of level I,II,III & $594(73.3)$ & $420(68.0)$ \\
\hline Surgeries of level IV & $216(26.7)$ & $198(32.0)$ \\
\hline
\end{tabular}

Table 1 reports the demographics and clinical characteristics and the presence of HRPOM exposure. The mean age ( \pm standard deviation, [SD]) of patients was $73.3( \pm 6.7$, range: $65-95), 50.7 \%$ were males. The mean day of hospital stay was 9.9 days ( \pm 10.1 , range: $0-122)$. The mean number of distinct diagnoses at discharge was 4.5 ( \pm 3.1 , range: 1 19). The mean number of medications used during hospitalization was 23.7 ( \pm 14.3 , range: $1-101)$. The magnitude of surgery was categorized into 4 groups according to the Surgical Classification Management System of China. ${ }^{24}$ Figure 1 shows the distribution of the magnitude of the surgery and HRPOM exposure. The type of surgery was classified according to the International Classification of Diseases Clinical Modification of $9^{\text {th }}$ Revision Operations and Procedures (ICD-9-CM-3), including general surgery (36.3\%), ophthalmology (6.9\%), otolaryngology $(4.7 \%)$, gynecology $(3.3 \%)$, neurosurgery $(6.7 \%)$, urology $(10.1 \%)$, orthopedics $(23.7 \%)$ and thoracic surgery $(8.3 \%)$.

The contribution of HRPOMs identified is showed in Table 2. 2113 HRPOMs which were identified in the study involved 42 medications and 12 categories including of cardiovascular system (20.9\%), urinary system (12.6\%), hematological system (17.2\%), central nervous system (10.9\%), endocrine system (17.4\%), gastrointestinal system (2.7\%), 1st-generation anti-allergic (3.4\%), anesthetics or anesthesia-assisted (1.6\%), anti-inflammatory and antirheumatic $(12.4 \%)$, anti-infective $(0.7 \%)$, respiratory $(0.1 \%)$ and other medications (0\%). As shown in Figure 2, the top 20 medications comprised $93.5 \%$ of the HRPOMs.

Table 3 reports the crude and adjusted odds for the occurrence of HRPOM exposure according to the variables. Upon univariate analysis, patients who were 70 years or older, or stayed in the hospital longer than 7 days were at higher risk of HRPOM exposure. The female patients were more likely to encounter HRPOM exposure than the male patients. Those with HRPOM exposure at discharge were significantly more likely to have more than 2 diagnoses or to use more than 15 medications during their hospitalization. Additionally, patients who underwent surgeries of Grade IV suffered more likelihood of HRPOM exposure than those who underwent surgeries of Grade III or lower.

Multivariate analysis showed there were positive associations between HRPOM exposure and age, the number of diagnoses at discharge, days of hospital stay and the number of medications used during hospitalization. Besides, patients who underwent surgeries of Grade IV were at 1.73 times increased odds of HRPOM exposure.

\section{Discussion}

The objective of our study was to investigate the previously unidentified prevalence of HRPOM exposure for the elderly in a Chinese university-affiliated general hospital, and verify the new-developed HRPOM list for the elderly. To our knowledge, this study is the first attempt to use a Chinese representative sample regarding the elderly surgical patients admitted to 8 common surgical wards to estimate the prevalence of HRPOMs with the use of a new-developed list of HRPOMs for the elderly. During our study, application of the HRPOM list had not yet been published for any settings.

Our findings revealed a total number of 2113 HRPOMs in a total number of 19,224 medications, and 618 participants encountered HRPOM exposure (76.3\%). The preexisting medication review concerning perioperative medication for the elderly is limited. 486 participants in our study encountered HRPOMs related to chronic 


\section{Surgeries of Grade I}

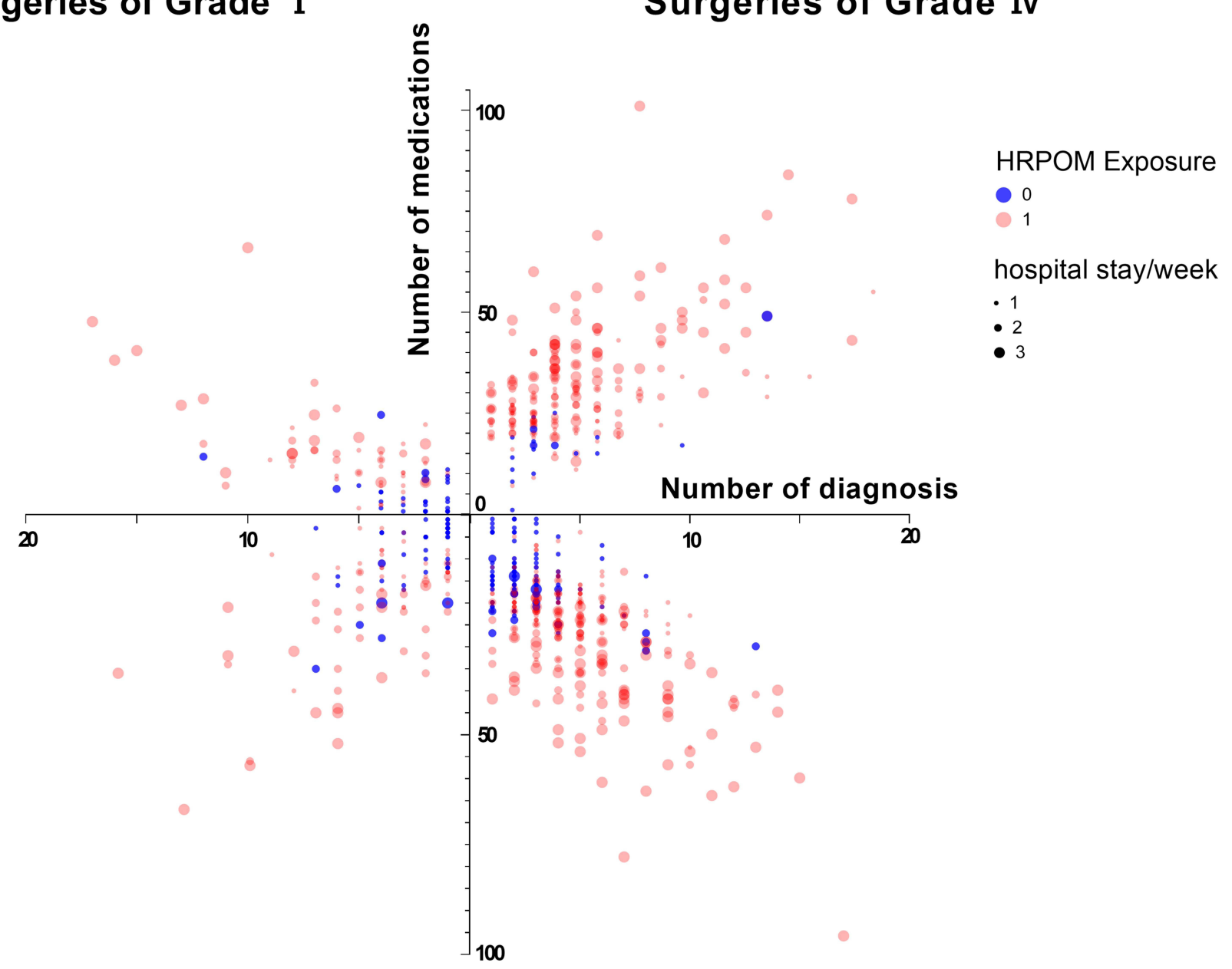

\section{Surgeries of Grade II}

\section{Surgeries of Grade III}

Figure I The distribution of the number of diagnosis and medications, hospital stay per week and HRPOM exposure according to the magnitude of surgery. Notes: Hospital stay/week: I: $\leq 7$ days, 2: 8 14 days, 3: $\geq 15$ days. The occurrence of HRPOM exposure of patients with surgeries of Grade IV was $91.7 \%$ compared with $66.3 \%$ for those with surgeries of Gradel, $62.8 \%$ for those with surgeries of Gradelland $74.0 \%$ for those with surgeries of Grade III.

diseases $(60.0 \%)$, while the previously reported prevalence of potentially inappropriate medications (PIMs) in Chinese hospitalized older patients ranged from $53.5 \%$ to $72.5 \%,{ }^{25,26}$ whereas few literature showed the prevalence of PIM in surgical patients was from $42.3 \%$ to $77.6 \%{ }^{27-29}$ The HRPOM list for the elderly complies well with previously published PIM criteria.

HRPOMs generally included two supercategories in our study, drugs related to surgery such as analgesics, anesthetics, sedatives and anti-infective agents and drugs related to chronic non-communicable diseases such as antihypertensives, hypoglycemics and antimyocardial ischemia agents. HRPOMs related to surgery in our study comprised $50.5 \%$ while $46.5 \%$ for HRPOMs related to chronic non-communicable diseases. Drugs related to surgery usually involve anesthesia, induced anesthesia and post-surgical complications such as pain, delirium, bleeding, thrombosis and infection. In the first place, the HRPOMs referred to non-steroidal anti-inflammatory drugs (NSAIDs, aspirin $\leq 100 \mathrm{mg} /$ day excluded) that were used by 257 participants $(31.7 \%)$. The utilization rate of NSAIDs in our study was much higher than what was reported in previous literature regarding geriatric medication $^{26,30,31}$ mainly due to their foundational role in postsurgical analgesic, anti-inflammatory, anti-stress ${ }^{32}$ and anti-fever. Whereas the short-term use of postsurgical NSAIDs is associated with increased risk of bleeding ${ }^{33}$ and acute kidney injury ${ }^{34}$ especially in the older population and/or patients with related underlying medical conditions. The second-most HRPOM related to surgery was 
Table 2 HRPOMs and the Concomitant Conditions and Potential Risks Identified in the Study and Recommendations According to the List

\begin{tabular}{|c|c|c|c|c|}
\hline Class & Conditions & Potential Risks & Recommendation & Number (\%) \\
\hline \multicolumn{5}{|l|}{$\begin{array}{l}\text { Cardiovascular system } \\
\text { medications }\end{array}$} \\
\hline Beta-blocking agents & l & $\begin{array}{l}\text { Withdrawal increases the risk of angina } \\
\text { exacerbation, myocardial infarction or } \\
\text { even sudden death, Continued using } \\
\text { can reduce the incidence of } \\
\text { postoperative atrial fibrillation and } \\
\text { avoid withdrawal syndrome }\end{array}$ & $\begin{array}{l}\text { I.Continue to use during the } \\
\text { perioperative period } 2 \text {.Pay } \\
\text { attention to monitoring blood } \\
\text { pressure and pulse }\end{array}$ & $69(3.3 \%)$ \\
\hline $\begin{array}{l}\text { Alpha-adrenoreceptor } \\
\text { antagonists }\end{array}$ & $\begin{array}{l}\text { General } \\
\text { anesthesia }\end{array}$ & $\begin{array}{l}\text { Increases risk of postural hypotension } \\
\text { and bradycardia }\end{array}$ & $\begin{array}{l}\text { I.Closely monitor blood pressure } \\
\text { during the surgery } 2 . \text { Use with } \\
\text { caution after surgery }\end{array}$ & $5(0.2 \%)$ \\
\hline \multirow[t]{2}{*}{ ACEI/ARB } & $\begin{array}{l}\text { Potassium-sparing } \\
\text { diuretics }\end{array}$ & Increases risk of hyperkalemia & $\begin{array}{l}\text { Avoid combining Potassium- } \\
\text { sparing diuretics (except patients } \\
\text { with hypokalemia) }\end{array}$ & \multirow[t]{2}{*}{$220(10.4 \%)$} \\
\hline & $\begin{array}{l}\text { Non-cardiac } \\
\text { surgery }\end{array}$ & $\begin{array}{l}\text { Potential hypotension risk during } \\
\text { induction of anesthesia }\end{array}$ & $\begin{array}{l}\text { Use with caution during the } \\
\text { perioperative period, pay attention } \\
\text { to monitoring blood pressure and } \\
\text { electrolyte levels }\end{array}$ & \\
\hline Organic nitrates & 1 & $\begin{array}{l}\text { Continued using helps control blood } \\
\text { pressure and angina, but affects } \\
\text { intraoperative blood pressure }\end{array}$ & $\begin{array}{l}\text { Continue to use, pay attention to } \\
\text { monitoring intraoperative blood } \\
\text { pressure }\end{array}$ & $122(5.8 \%)$ \\
\hline \multirow[t]{2}{*}{$\begin{array}{l}\text { Antiarrhythmics, class III } \\
\text { (amiodarone) }\end{array}$} & 1 & $\begin{array}{l}\text { Severe arrhythmia (QT interval } \\
\text { prolongation and torsades de pointes); } \\
\text { Withdrawal can not control arrhythmia } \\
\text { symptoms }\end{array}$ & Closely monitor ECG & \multirow[t]{2}{*}{$20(0.9 \%)$} \\
\hline & $\begin{array}{l}\text { Halogenated } \\
\text { inhalation } \\
\text { anesthetics }\end{array}$ & $\begin{array}{l}\text { Risk of enhanced myocardial inhibition } \\
\text { and conduction, increases risk of } \\
\text { postoperative acute respiratory } \\
\text { distress syndrome (ARDS) }\end{array}$ & $\begin{array}{l}\text { Use halogenated inhaled } \\
\text { anesthetics with caution during the } \\
\text { surgery }\end{array}$ & \\
\hline $\begin{array}{l}\text { Rauwolfia alkaloids } \\
\text { (reserpine) }\end{array}$ & 1 & $\begin{array}{l}\text { Increases the risk of refractory } \\
\text { hypotension during the surgery }\end{array}$ & $\begin{array}{l}\text { Stop I-2w before surgery, for } \\
\text { emergency/limited surgery, } \\
\text { prepare for norepinephrine }\end{array}$ & $2(0.1 \%)$ \\
\hline Digoxin $>0.125 \mathrm{mg} / \mathrm{d}$ & 1 & Arrhythmia & $\begin{array}{l}\text { Use with caution, pay attention to } \\
\text { monitoring the concentration of } \\
\text { digoxin and potassium level }\end{array}$ & $4(0.2 \%)$ \\
\hline \multicolumn{5}{|l|}{$\begin{array}{l}\text { Urinary system } \\
\text { medications }\end{array}$} \\
\hline Thiazines & 1 & $\begin{array}{l}\text { Affects electrolytes and blood volume } \\
\text { levels }\end{array}$ & $\begin{array}{l}\text { Continue to use, pay attention to } \\
\text { monitoring blood pressure and } \\
\text { electrolyte levels }\end{array}$ & $53(2.5 \%)$ \\
\hline Loop diuretics & l & $\begin{array}{l}\text { Affects electrolytes and blood volume } \\
\text { levels, increases risk of electrolyte } \\
\text { imbalance and hypotension }\end{array}$ & $\begin{array}{l}\text { Stop on the day of surgery or } \\
\text { discretion according to the } \\
\text { specialist situation }\end{array}$ & $178(8.4 \%)$ \\
\hline
\end{tabular}

(Continued) 
Table 2 (Continued).

\begin{tabular}{|c|c|c|c|c|}
\hline Class & Conditions & Potential Risks & Recommendation & Number (\%) \\
\hline $\begin{array}{l}\text { Potassium-sparing } \\
\text { diuretics }\end{array}$ & 1 & Increases risk of hyperkalemia & $\begin{array}{l}\text { Stop on the day of surgery or } \\
\text { discretion according to the } \\
\text { specialist situation, monitor } \\
\text { Potassium levels }\end{array}$ & $36(1.7 \%)$ \\
\hline \multicolumn{5}{|l|}{$\begin{array}{l}\text { Hematological system } \\
\text { medications }\end{array}$} \\
\hline Clopidogrel & 1 & Increases risk of bleeding & $\begin{array}{l}\text { Comprehensive assessment, if you } \\
\text { need to stop, stop } 5-7 d \text { before } \\
\text { surgery }\end{array}$ & $40(1.9 \%)$ \\
\hline Cilostazol & 1 & Increases risk of bleeding & $\begin{array}{l}\text { Comprehensive assessment, if you } \\
\text { need to stop, stop } 3-5 d \text { before } \\
\text { surgery }\end{array}$ & $8(0.4 \%)$ \\
\hline Warfarin & Elective surgery & Increases risk of bleeding & $\begin{array}{l}\text { Stop } 3-5 d \text { before surgery, monitor } \\
\text { INR (ideally } \leq 1.5 \text { ) and bleeding } \\
\text { situation }\end{array}$ & $5(0.2 \%)$ \\
\hline $\begin{array}{l}\text { Low molecular weight } \\
\text { heparin }\end{array}$ & 1 & Increases risk of bleeding & $\begin{array}{l}\text { I.Therapeutic: stop } 24 \mathrm{~h} \text { before } \\
\text { surgery } 2 . \text { Prophylaxis: stop } 12 \mathrm{~h} \\
\text { before surgery } 3 . \text { Discretion } \\
\text { according to the specialist situation }\end{array}$ & $126(6 \%)$ \\
\hline Asprin $(\leq 100 \mathrm{mg} /$ day $)$ & 1 & Increases risk of bleeding & $\begin{array}{l}\text { Use with caution and monitor } \\
\text { bleeding situation }\end{array}$ & $76(3.6 \%)$ \\
\hline Heparin & 1 & & & $36(1.7 \%)$ \\
\hline Rivaroxaban & 1 & & & $73(3.5 \%)$ \\
\hline \multicolumn{5}{|l|}{$\begin{array}{l}\text { Central nervous system } \\
\text { medications }\end{array}$} \\
\hline $\begin{array}{l}\text { Benzodiazepine } \\
\text { derivatives }\end{array}$ & I & $\begin{array}{l}\text { Increases risk of delirium, fall, cognitive } \\
\text { impairment and hypotension }\end{array}$ & $\begin{array}{l}\text { Use with caution during the } \\
\text { perioperative period; monitor } \\
\text { blood pressure }\end{array}$ & $103(4.9 \%)$ \\
\hline Z-drugs & 1 & $\begin{array}{l}\text { Increases risk of delirium, fall and } \\
\text { cognitive impairment }\end{array}$ & $\begin{array}{l}\text { Use with caution during the } \\
\text { perioperative period }\end{array}$ & $2(0.1 \%)$ \\
\hline $\begin{array}{l}\text { Phenothiazines } \\
\text { (perphenazine) }\end{array}$ & 1 & $\begin{array}{l}\text { Can enhance CNS depression, lower } \\
\text { seizure threshold, cause ECG } \\
\text { abnormalities, arrhythmias, } \\
\text { hypotension, neuroleptic malignant } \\
\text { syndrome; discontinuation associated } \\
\text { with withdrawal dyskinesia and } \\
\text { rebound agitation }\end{array}$ & $\begin{array}{l}\text { Continue to use with caution } \\
\text { during the perioperative period, } \\
\text { pay attention to monitoring }\end{array}$ & $4(0.2 \%)$ \\
\hline \multirow[t]{2}{*}{$\begin{array}{l}\text { Phenothiazines } \\
\text { (chlorpromazine) }\end{array}$} & 1 & Increases risk of delirium & $\begin{array}{l}\text { Use with caution during the } \\
\text { perioperative period }\end{array}$ & \multirow[t]{2}{*}{$2(0.1 \%)$} \\
\hline & $\begin{array}{l}\text { General } \\
\text { anesthesia }\end{array}$ & $\begin{array}{l}\text { Increases risk of postural hypotension } \\
\text { and bradycardia }\end{array}$ & $\begin{array}{l}\text { I.Closely monitor blood pressure } \\
\text { during the surgery } \\
\text { 2.Use with caution after surgery }\end{array}$ & \\
\hline
\end{tabular}

(Continued) 
Table 2 (Continued).

\begin{tabular}{|c|c|c|c|c|}
\hline Class & Conditions & Potential Risks & Recommendation & Number (\%) \\
\hline Dexmedetomidine & l & $\begin{array}{l}\text { Increases risk of hypotension and non- } \\
\text { fatal cardiac arrest }\end{array}$ & $\begin{array}{l}\text { Closely monitor blood pressure } \\
\text { and pulse }\end{array}$ & $\operatorname{ll}(5.3 \%)$ \\
\hline SSRIs & I & $\begin{array}{l}\text { Nervous system adverse reactions } \\
\text { (insomnia, dizziness, unconsciousness, } \\
\text { upset and agitation) }\end{array}$ & $\begin{array}{l}\text { Pay attention to the symptoms of } \\
\text { the nervous system }\end{array}$ & $5(0.2 \%)$ \\
\hline $\begin{array}{l}\text { Anti-Parkinson drugs } \\
\text { (levodopa and } \\
\text { benserazide) }\end{array}$ & $\begin{array}{l}\text { Halothane } \\
\text { anesthesia }\end{array}$ & $\begin{array}{l}\text { Increases intraoperative blood pressure } \\
\text { fluctuations and risk of arrhythmia }\end{array}$ & Stop $12-48 \mathrm{~h}$ before surgery & $3(0.1 \%)$ \\
\hline \multicolumn{5}{|l|}{$\begin{array}{l}\text { Endocrine system } \\
\text { medications }\end{array}$} \\
\hline Glucocorticoids & NSAIDs & Increases risk of bleeding & Monitoring bleeding situation & $189(8.9 \%)$ \\
\hline \multirow[t]{2}{*}{ Metformin } & Renal insufficiency & \multirow[t]{2}{*}{ Increases risk of lactic acidosis } & Stop $48 \mathrm{~h}$ before surgery & \multirow[t]{2}{*}{$50(2.4 \%)$} \\
\hline & $\begin{array}{l}\text { Intraoperative } \\
\text { venous contrast }\end{array}$ & & $\begin{array}{l}\text { Monitor renal function after } 2-3 \\
\text { days of radiography and restart } \\
\text { after normal results }\end{array}$ & \\
\hline Quick/Short-acting insulin & $\begin{array}{l}\text { Surgery requiring } \\
\text { fasting water }\end{array}$ & Increases risk of hypoglycemia & Stop on the day of surgery & $92(4.4 \%)$ \\
\hline Sulfonylureas & $\begin{array}{l}\text { Surgery requiring } \\
\text { fasting water }\end{array}$ & Increases risk of hypoglycemia & Stop on the day of surgery & $24(1.1 \%)$ \\
\hline Non-sulfonylureas & $\begin{array}{l}\text { Surgery requiring } \\
\text { fasting water }\end{array}$ & Increases risk of hypoglycemia & Stop on the day of surgery & $8(0.4 \%)$ \\
\hline Thiazolidinediones & 1 & $\begin{array}{l}\text { Increases risk of hypoglycemia and } \\
\text { postoperative fluid retention }\end{array}$ & Stop on the day of surgery & $4(0.2 \%)$ \\
\hline \multicolumn{5}{|l|}{$\begin{array}{l}\text { Gastrointestinal system } \\
\text { medications }\end{array}$} \\
\hline Scopolamine & 1 & $\begin{array}{l}\text { Increases risk of delirium and cognitive } \\
\text { impairment }\end{array}$ & $\begin{array}{l}\text { Use with caution during the } \\
\text { perioperative period }\end{array}$ & $58(2.7 \%)$ \\
\hline \multicolumn{5}{|l|}{$\begin{array}{l}\text { Antiallergic medications, } \\
\text { Ist-generation }\end{array}$} \\
\hline Promethazine & 1 & \multirow{2}{*}{$\begin{array}{l}\text { Increases risk of delirium and } \\
\text { potentially enhances the sedative effect } \\
\text { of general anesthetics }\end{array}$} & \multirow[t]{2}{*}{ Stop Id before surgery } & $\mathrm{II}(0.5 \%)$ \\
\hline Chlorphenamine & I & & & $62(2.9 \%)$ \\
\hline \multicolumn{5}{|l|}{$\begin{array}{l}\text { Anesthetics or anesthesia- } \\
\text { assisted medications }\end{array}$} \\
\hline Propofol & $\begin{array}{l}\text { Serious heart } \\
\text { disease (ejection } \\
\text { fraction }<50 \% \text { ) }\end{array}$ & $\begin{array}{l}\text { Increases risk of serious cardiovascular } \\
\text { adverse reactions }\end{array}$ & $\begin{array}{l}\text { Closely monitor circulatory } \\
\text { function during the perioperative } \\
\text { period }\end{array}$ & $7(0.3 \%)$ \\
\hline Rocuronium Bromide & $\begin{array}{l}\text { Impaired liver } \\
\text { function }\end{array}$ & $\begin{array}{l}\text { Mainly excreted by bile, prone to } \\
\text { accumulation }\end{array}$ & $\begin{array}{l}\text { Avoid using drugs that aggravate } \\
\text { liver damage during the surgery }\end{array}$ & $2(0.1 \%)$ \\
\hline Pethidine & 1 & $\begin{array}{l}\text { Increases risk of fall, seizure and } \\
\text { delirium }\end{array}$ & $\begin{array}{l}\text { Avoid using during the } \\
\text { perioperative period }\end{array}$ & $24(1.1 \%)$ \\
\hline
\end{tabular}


Table 2 (Continued).

\begin{tabular}{|c|c|c|c|c|}
\hline Class & Conditions & Potential Risks & Recommendation & Number (\%) \\
\hline \multicolumn{5}{|l|}{$\begin{array}{l}\text { Anti-inflammatory and } \\
\text { anti-rheumatic } \\
\text { medications }\end{array}$} \\
\hline \multirow[t]{2}{*}{$\begin{array}{l}\text { NSAIDs (Aspirin } \leq 100 \mathrm{mg} / \\
\text { day excluded) }\end{array}$} & Renal insufficiency & $\begin{array}{l}\text { Retention of water and sodium, can } \\
\text { aggravate or cause kidney failure }\end{array}$ & $\begin{array}{l}\text { Avoid using during the } \\
\text { perioperative period }\end{array}$ & $6(0.3 \%)$ \\
\hline & $\begin{array}{l}\text { Major orthopedic } \\
\text { surgery }\end{array}$ & $\begin{array}{l}\text { Increases risk of bleeding and kidney } \\
\text { damage }\end{array}$ & $\begin{array}{l}\text { Stop } 4-7 d \text { before surgery or } \\
\text { discretion according to the } \\
\text { specialist situation }\end{array}$ & $251(11.9 \%)$ \\
\hline Colchicine & l & $\begin{array}{l}\text { The therapeutic index is narrow and } \\
\text { can cause muscle weakness and } \\
\text { polyneuropathy in the setting of renal } \\
\text { impairment or drug interactions }\end{array}$ & Stop on the day of surgery & $4(0.2 \%)$ \\
\hline \multicolumn{5}{|l|}{ Anti-infective medications } \\
\hline $\begin{array}{l}\text { Vancomycin, } \\
\text { aminoglycosides }\end{array}$ & l & Increases risk of kidney damage & Monitor renal function & $\mathrm{II}(0.5 \%)$ \\
\hline \multirow[t]{2}{*}{ Linezolid } & $\begin{array}{l}\text { Sympathomimetic } \\
\text { drugs }\end{array}$ & Increases risk of hypertensive crisis & Avoid using together & \multirow[t]{2}{*}{$4(0.2 \%)$} \\
\hline & Meperidine & Increases risk of 5-HT syndrome & Avoid using together & \\
\hline \multicolumn{5}{|l|}{ Respiratory medications } \\
\hline Xanthines (aminophylline) & l & $\begin{array}{l}\text { The therapeutic window is narrow, can } \\
\text { cause arrhythmia and neurotoxicity if } \\
\text { drug levels become supratherapeutic }\end{array}$ & $\begin{array}{l}\text { Stop } 24 \mathrm{~h} \text { before surgery or } \\
\text { discretion according to the } \\
\text { specialist situation }\end{array}$ & $2(0.1 \%)$ \\
\hline \multicolumn{5}{|l|}{ Other medications } \\
\hline Rituximab & l & Potential risk of infection & $\begin{array}{l}\text { Depending on the drug, stop at } \\
\text { two half-lives or at least one } \\
\text { dosing interval before surgery }\end{array}$ & $\mathrm{I}(0 \%)$ \\
\hline
\end{tabular}

Abbreviations: ACEI/ARB, angiotensin-converting enzyme inhibitors and angiotensin receptor blockers; ECG, electrocardiogram; INR, international normalized ratio; Z-drugs, non-benzodiazepine receptor agonists, referred to dexzopiclone, zolpidem and zaleplon; CNS, central nervous system; NSAIDs, non-steroidal anti-inflammatory drugs.

constituted by the glucocorticoids with concomitant NSAIDs (used by 189 participants, 23.3\%). Glucocorticoids identified in our study were used to prevent or treat postoperative nausea and vomiting, ${ }^{35,36}$ airway hyperresponsiveness, ${ }^{37}$ allergy and inflammatory complications. The combination of glucocorticoids and NSAIDs increased the risk of gastrointestinal bleeding and ulcer. ${ }^{16,38,39}$ HRPOMs related to surgery identified in our study potentially increased the occurrence of postoperative complications and thus increased the day of hospital stay and swelled the treatment cost.

Drugs related to chronic diseases were introduced to treat chronic comorbid conditions such as hypertension, diabetes, heart disease and ischemic stroke. Regarding this supercategory, Angiotensin-Converting Enzyme Inhibitors and Angiotensin Receptor Blockers (ACEI/ARB) for hypertension held the predominant proportion as 220 participants in our study used them (27.2\%). Hypertension is the most common chronic disease in Chinese older people, and the incidence was $55.7 \%$ for the population aged 65 to 74 years and $60.2 \%$ for the population aged 75 years or older. $^{40}$ Our study showed the prevalence of hypertension in the elder surgical patients was $50.2 \%$, which fitted the previous survey. And the utilization rate of ACEI/ARB in our study was $54.1 \%$ compared with $27.4 \%$ as reported in the survey. Diuretics and calcium channel blockers (CCBs) 


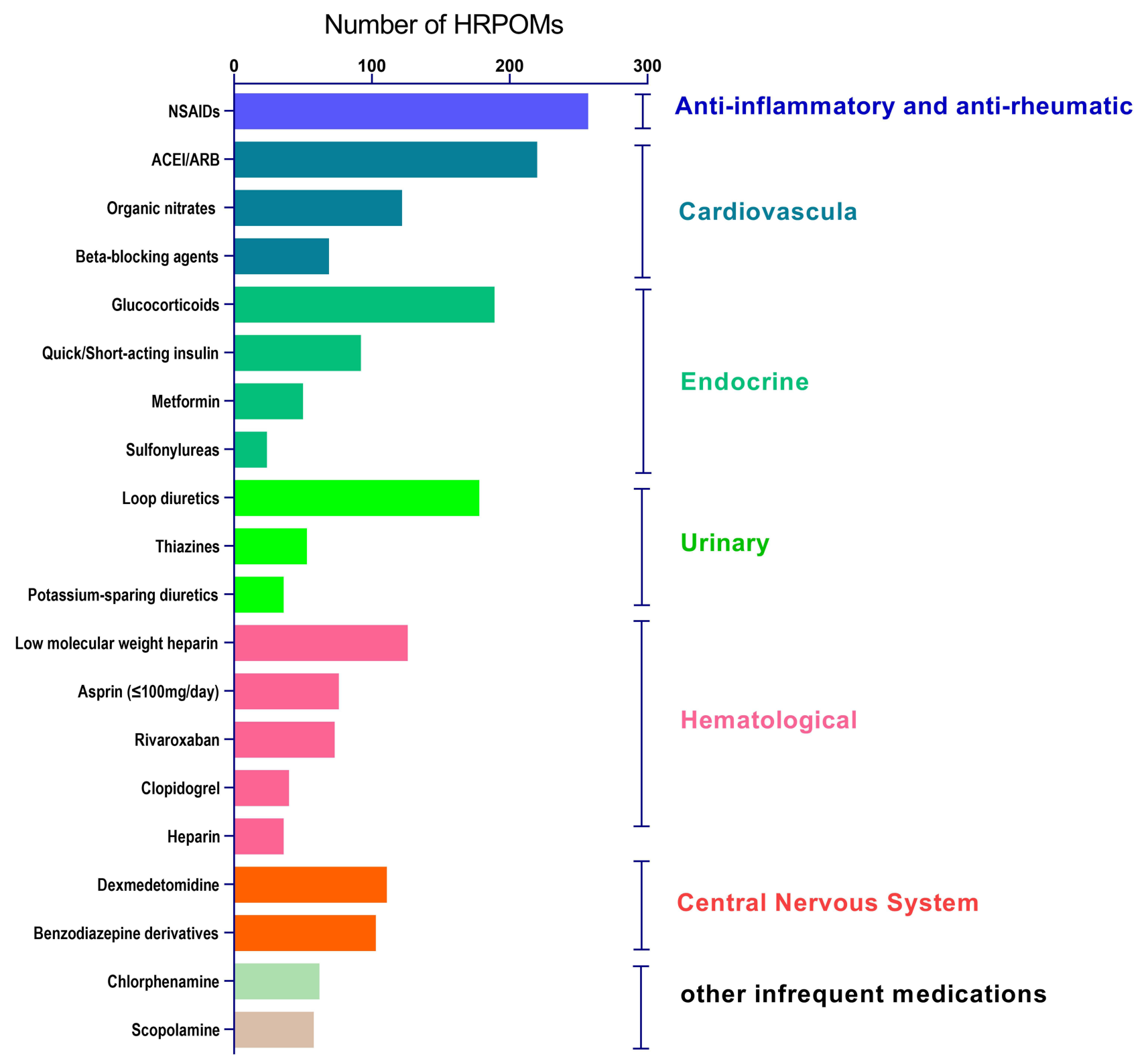

Figure 2 The distribution of the top 20 HRPOMs, which comprised $93.5 \%$ of the HRPOMs identified in the study.

Abbreviations: NSAIDs, non- steroidal anti-inflammatory drugs; ACEI, angiotensin-converting enzyme Inhibitor; ARB, angiotensin receptor blocker.

were reported as the two most frequently used antihypertensive agents in China, while our study revealed the perioperative prescription of diuretics was limited mainly owing to their potential effect on electrolytes and blood volume levels. Moreover, according to the HRPOMs list, perioperative use of CCBs was proved to be safe enough except in vasospastic angina patients ${ }^{14,41,42}$ who were not found in this audit. The withholding of ACEI/ARB in the perioperative period was associated with a lower risk of death and postoperative vascular events ${ }^{19}$ while a higher prevalence of intraoperative hypotension. ${ }^{43}$ And when combining with potassium-sparing diuretics, ACEI/ARB raises the risk of hyperkalemia. Note that the withdrawal of the drugs results in fluctuation of blood pressure. HRPOMs related to chronic diseases were contended to mask the predisposing frailty of patients and/or reduce the severity of chronic comorbidities. ${ }^{1}$ Take ACEI/ARB for example, inappropriate withholding or withdrawal of HRPOMs easily brings more harm than benefit.

The demographic and clinical variables were carefully grouped to reveal their associations with HRPOM exposure. Age, the number of distinct diagnoses, days of hospital stay and medications used during hospitalization were independent predictors for HRPOM exposure in our 
Table 3 Crude and Adjusted Odds Ratios $(95 \% \mathrm{Cl}$ ) for HRPOM Exposure in the Study Population in Jinshan Hospital of Fudan University, Shanghai, China, Between Jan Ist and June 30th, 2020

\begin{tabular}{|c|c|c|}
\hline $\begin{array}{l}\text { Demographic and Clinical } \\
\text { Characteristics }\end{array}$ & $\begin{array}{r}\text { Crude OR of HRPOM Exposure(95\% CI), } \\
\text { P-value }\end{array}$ & $\begin{array}{r}\text { Adjusted OR of HRPOM Exposure (95\% CI), } \\
\text { P-value }\end{array}$ \\
\hline \multicolumn{3}{|l|}{ Sex, n (\%), } \\
\hline Female & I & I \\
\hline Male & $0.633(0.456 \sim 0.879), P=0.006 \mathrm{I}$ & $1.013(0.652 \sim 1.575), P=0.954$ \\
\hline \multicolumn{3}{|l|}{ Age } \\
\hline $65 \sim 69$ & I & I \\
\hline$\geq 70$ & 2.698 (I.937 3.758), $P<0.000 \mathrm{I}$ & 2.118 (I.420 3.159), $P<0.0001$ \\
\hline \multicolumn{3}{|l|}{ Days of hospital stay } \\
\hline$\leq 7$ & 1 & I \\
\hline $8 \sim 14$ & $4.37 \mathrm{I}(2.793 \sim 6.842), \mathrm{P}<0.000 \mathrm{I}$ & I.448(0.844 2.484), $\mathrm{P}=0.179$ \\
\hline$\geq 15$ & 19.589(7.874 48.738), $\mathrm{P}<0.000 \mathrm{I}$ & 4. $192(|.493 \sim| I .77 \mid), P=0.007$ \\
\hline \multicolumn{3}{|l|}{ Number of distinc diagnoses } \\
\hline $1 \sim 2$ & 1 & I \\
\hline $3 \sim 5$ & $4.646(3.183 \sim 6.78 \mathrm{I}), \mathrm{P}<0.000 \mathrm{I}$ & 3.407(2.224 5.220), $\mathrm{P}<0.000 \mathrm{I}$ \\
\hline$\geq 6$ & $10.01 \mathrm{I}(5.858 \sim 17.1 \mathrm{I} 0), \mathrm{P}<0.000 \mathrm{I}$ & 2.938 (I.573 5.487), $\mathrm{P}=0.00 \mathrm{I}$ \\
\hline \multicolumn{3}{|l|}{ Number of medications } \\
\hline$\leq 15$ & I & I \\
\hline $16 \sim 24$ & 5.053(3.407 7.493), $\mathrm{P}<0.000 \mathrm{I}$ & $3.738(2.4 \mid 3 \sim 5.791), P<0.000 \mathrm{I}$ \\
\hline$\geq 25$ & $28.25 \mathrm{I}(15.255 \sim 52.3 \mathrm{I} 8), \mathrm{P}<0.000 \mathrm{I}$ & 9.397(4.4I6 19.996), $P<0.000 \mathrm{I}$ \\
\hline \multicolumn{3}{|l|}{ Grade of surgeries } \\
\hline Surgeries of level I,II,III & 1 & I \\
\hline Surgeries of level IV & 4.557(2.726 7.6I8), $\mathrm{P}<0.000 \mathrm{I}$ & 1.730 (0.954 3.|37), $P=0.07 \mid$ \\
\hline
\end{tabular}

study. The elderly are more likely to be assailed by chronic health conditions, the number and severity of which also increase with age. Moreover, poorly managed chronic diseases often result in other organs' injury and multiple chronic complications, which contributed to the number of distinct diagnoses. Compared with the reference group, patients with 3 or more diagnoses were around 3 times likely to experience HRPOM exposure in our study, which agreed with PIM presence in hospitalized medical patients reported previously. ${ }^{44}$ Medical patients prefer pharmacotherapy rather than non-drug methods to treat each distinct diagnosis and thus receive more high-risk medications, ${ }^{26}$ whereas surgical patients are more positive to surgical approaches for each distinct diagnosis.

It is noticeable that the occurrence of HRPOM exposure significantly increased with the number of medications in our study. The mean number of drugs used during hospitalization was 23.7, which was far more than the number defined by polypharmacy. Polypharmacy was generally defined as taking five or more medications. ${ }^{45}$ This provides further evidence to previous studies that more medications mean more risks. ${ }^{4,26-29,31}$ Given the poor health status and medication adherence, the elderly on polypharmacy are at higher risk of adverse drug events than the population of younger age or/and without polypharmacy. ${ }^{46}$

The days of hospital stay were usually regarded as one of the hospitalization outcomes, while in our study this variable also contributed to HRPOMs. Patients hospitalized over two weeks were about 4 times more odds of HRPOM exposure than those hospitalized within one week. The elderly are susceptible to malnourished status, chronic conditions and surgical complications and thus easily suffered from extended length of hospital stay. ${ }^{47}$ Nevertheless, patients with an excessive length of hospital stay are vulnerable to complications such as stress and deep venous thrombosis, ${ }^{48}$ which increased the presence of high-risk medications as reported in preexisting literature. ${ }^{27,31}$

Surgeries were categorized into four groups according to the magnitude of the surgery, and surgeries of Grade IV were of the highest risk of postsurgical complications and 
mortality. Logistic regression revealed HRPOM exposure was scarcely associated with the magnitude of surgery. Patients who underwent surgeries of Grade IV were at 1.73 times increased odds of HRPOM exposure than those with surgeries of Grade III or lower. Kennedy et al also reported a scarce association between postsurgical complications and the magnitude of surgery. ${ }^{1}$ Further, the $t$-test showed patients with surgeries of Grade IV possessed more diagnoses, used more medications and hospitalized for more days compared with those of the reference population. As discussed above, the magnitude of surgery contributed to HRPOM exposure via the increasing days of hospital stay and the number of distinct diagnoses and medications.

The limitations of this study must be acknowledged. First, this medication audit was conducted from a resource within a single hospital and thus biases preexist in the spectra of surgeries and other clinical variables. Participants from some surgical wards tended to undergo day-surgeries or lower magnitude of surgeries and thus used fewer medications. HRPOM exposure of these participants was relatively fewer. Second, information from this analysis was limited because hospital records are not designed for research purposes, and their diagnostic quality may vary depending upon each surgeon and clinical unit, as data on surgical outcomes including postsurgical complications and mortality was not recorded. Thus, the impact of HRPOMs upon surgical outcomes remains unclear.

Even though this is the first study to reveal the highrisk medications used in the perioperative period for elderly patients in China, further research is necessary. Studies that use data from multiple medical centers would avoid static biases. And well-designed prospective studies including postsurgical complications and other clinical characteristics that we failed to collect would help to elucidate the impact of HRPOMs on the older surgical patients and further validate the HRPOMs list for the elderly.

\section{Conclusion}

We have uncovered the prevalence of HRPOMs for the elderly in a Chinese general hospital, and verified the HRPOM list for the elderly. HRPOMs were found to be more common in patients of 70 years or older, and those with more diagnoses, medications and days of hospital stay were at more odds to expose to HRPOMs. The magnitude of surgery was scarcely associated with HRPOM exposure. HRPOMs identified in our study comprehensively comprised not only chronic medications but also medications related to surgery. The effectiveness of the HRPOM list for the elderly was thus verified. Our study may provoke prospective research to assess the adverse effects of high-risk medications on the elderly's surgical outcomes. And pharmaceutical care should be applied to monitor drug-related complications of elderly surgical patients and optimize their surgical outcomes.

\section{Ethics Statement}

The ethics approval was waived by the Ethics Committee of Jinshan Hospital, Fudan University in Shanghai, China, as the study was a clinical audit. The patient data was anonymized, and complied with relevant data protection and privacy regulations.

\section{Funding}

The work was funded by a grant from the Key Construction Project on Clinical Pharmacy of Shanghai Municipal Health Commission (2019-1229).

\section{Disclosure}

$\mathrm{Mr}$ Yuan Gong reported grants from Shanghai Pharmaceutical Association, during the conduct of the study. The authors report no other conflicts of interest in this work.

\section{References}

1. Kennedy JM, van Rij AM, Spears GF, Pettigrew RA, Tucker IG. Polypharmacy in a general surgical unit and consequences of drug withdrawal. Br J Clin Pharmacol. 2000;49(4):353-362.

2. Bainbridge D, Martin J, Arango M, Cheng D. Perioperative and anaesthetic-related mortality in developed and developing countries: a systematic review and meta-analysis. Lancet. 2012;380 (9847):1075-1081.

3. Dutta S, Cohn SL, Pfeifer KJ, Slawski BA, Smetana GW, Jaffer AK. Updates in perioperative medicine. J Hosp Med. 2016;11(3):231-236.

4. Nanji KC, Patel A, Shaikh S, Seger DL, Bates DW. Evaluation of perioperative medication errors and adverse drug events. Anesthesiology. 2016;124(1):25-34.

5. Sánchez-López VA, Hernández-Cañaveral I, Huerta-Olvera SG. Comparison between 2 electronic databases to evaluate potential drug-drug interactions in prescriptions of surgical patients. $\mathrm{Am}$ $J$ Ther. 2018;25(6):e686-e687.

6. American Geriatrics Society Beers Criteria ${ }^{\circledR}$ Update Expert Panel. American Geriatrics Society 2019. Updated AGS beers criteria ${ }^{\circledR}$ for potentially inappropriate medication use in older adults. $J$ Am Geriatr Soc. 2019;67(4):674-694.

7. O'Mahony D, O'Sullivan D, Byrne S, O'Connor MN, Ryan C, Gallagher P. STOPP/START criteria for potentially inappropriate prescribing in older people: version 2. Age Ageing. 2015;44(2):213-218.

8. Holt S, Schmiedl S, Thürmann PA. Potentially inappropriate medications in the elderly: the PRISCUS list. Deutsches Aerzteblatt Int. 2010;107(31-32):543-551. 
9. Basger BJ, Chen TF, Moles RJ. Inappropriate medication use and prescribing indicators in elderly australians. Drugs Aging. 2008;25 (9):777-793.

10. Laroche ML, Charmes JP, Merle L. Potentially inappropriate medications in the elderly: a French consensus panel list. Eur J Clin Pharmacol. 2007;63(8):725-731.

11. Zhan C, Sangl J, Bierman AS, Miller MR, Meyer GS. Potentially inappropriate medication use in the community-dwelling elderly: findings from the 1996 medical expenditure panel survey. JAMA. 2001;286(22):2823-2829.

12. Naugler CT, Brymer C, Stolee P, Arcese ZA. Development and validation of an improving prescribing in the elderly tool. Can j Clin Pharmacol. 2000;7(2):103.

13. Lee YK, Na SW, Kwak YL, Nam SB. Effect of pre-operative angiotensin-converting enzyme inhibitors on haemodynamic parameters and vasoconstrictor requirements in patients undergoing off-pump coronary artery bypass surgery. J Int Med Res. 2005;33(6):693-702.

14. Wijeysundera DN, Beattie WS. Calcium channel blockers for reducing cardiac morbidity after noncardiac surgery: a meta-analysis. Anesth Analg. 2003;97(3):634-641.

15. Tafur A, Douketis J. Perioperative management of anticoagulant and antiplatelet therapy. Heart. 2018;104(17):1461-1467.

16. Gribsholt SB, Svensson E, Thomsen RW, Richelsen B, Sørensen HT. Preoperative glucocorticoid use and risk of postoperative bleeding and infection after gastric bypass surgery for the treatment of obesity. Surg Obesity Rel Dis. 2015;11(6):1212-1217.

17. Shammash JB, Trost JC, Gold JM, Berlin JA, Golden MA, Kimmel SE. Perioperative beta-blocker withdrawal and mortality in vascular surgical patients. Am Heart J. 2001;141(1):148-153.

18. Seim LA, Irizarry-Alvarado JM. Perioperative management of female hormone medications. Curr Clin Pharmacol. 2017;12(3):188-193.

19. Roshanov PS, Rochwerg B, Patel A, et al. Withholding versus continuing angiotensin-converting enzyme inhibitors or Angiotensin II receptor blockers before noncardiac surgery: an analysis of the vascular events in noncardiac surgery patients cohort evaluation prospective cohort. Anesthesiology. 2017;126(1):16-27.

20. Pieringer H, Danninger K, Tzaribachev N, Böhler N, Pohanka E, Herold M. Patients with arthritis undergoing surgery: how should we manage tumour necrosis factor blocking agents perioperatively?-A systematic literature review. Yonsei Med J. 2013;54(1):253-257.

21. Wang K, Shen J, Jiang D, Xing X, Zhan S. Development of a list of high-risk perioperative medications for the elderly: a Delphi method. Expert Opin Drug Saf. 2019;18(63):853-859.

22. Comfere T, Sprung J, Kumar MM, et al. Angiotensin system inhibitors in a general surgical population. Anesth Analg. 2005;100 (3):636-644.

23. Wagner J, Luber V, Lock JF, et al. Perioperative handling of immunosuppressive therapy. Chirurg. 2018;89(2):116-121.

24. Notice on the issuance of medical institutions surgical grading management approach (a trial implementation). Available from: http:// www.nhc.gov.cn/wjw/ywfw/201306/def185b8d52e48918c f7e12e43e956d6.shtml.

25. Li H, Pu S, Liu Q, et al. Potentially inappropriate medications in Chinese older adults: the beers criteria compared with the screening tool of older persons' prescriptions criteria. Geriatr Gerontol Int. 2017;17(11):1951-1958.

26. Zhang X, Zhou S, Pan K, et al. Potentially inappropriate medications in hospitalized older patients: a cross-sectional study using the Beers 2015 criteria versus the 2012 criteria. Clin Interv Aging. 2017;12:1697-1703.

27. Iaboni A, Rawson K, Burkett C, Lenze EJ, Flint AJ. Potentially inappropriate medications and the time to full functional recovery after hip fracture. Drugs Aging. 2017;34(9):723-728.

28. da Costa IHF, Silva RME, Carlos JO, et al. Potentially inappropriate medications in older kidney transplant recipients: a Brazilian prevalence study. Int J Clin Pharm. 2019;41(4):888-894.
29. Nagai T, Nagaoka M, Tanimoto K, Tomizuka Y, Uei H, Nakanishi K. Relationship between potentially inappropriate medications and functional prognosis in elderly patients with distal radius fracture: a retrospective cohort study. J Orthop Surg Res. 2020;15(1):321.

30. Kim GJ, Lee KH, Kim JH. South Korean geriatrics on Beers Criteria medications at risk of adverse drug events. PLoS One. 2018;13(3): e0191376.

31. Wang P, Wang Q, Li F, Bian M, Yang K. Relationship between potentially inappropriate medications and the risk of hospital readmission and death in hospitalized older patients. Clin Interv Aging. 2019; 14:1871-1878.

32. Chou R, Gordon DB, de Leon-casasola OA, et al. Management of Postoperative Pain: a Clinical Practice Guideline From the American Pain Society, the American Society of Regional Anesthesia and Pain Medicine, and the American Society of Anesthesiologists' Committee on Regional Anesthesia, Executive Committee, and Administrative Council. J Pain. 2016;17(2):131-157.

33. Chinese Rheumatism Data Center, Chinese Systemic Lupus Erythematosus Treatment and Research Group. Recommendation for the prevention and treatment of non-steroidal anti-inflammatory drug-induced gastrointestinal ulcers and its complications. Zhonghua Nei Ke Za Zhi. 2017;56(1):81-85.

34. Bell S, Rennie T, Marwick CA, Davey P. Effects of peri-operative nonsteroidal anti-inflammatory drugs on post-operative kidney function for adults with normal kidney function. Cochrane Database Syst Rev. 2018;11(11):Cd011274.

35. Sinner B. Perioperative dexamethasone. Anaesthesist. 2019;68 (10):676-682.

36. Chen P, Li X, Sang L, Huang J. Perioperative intravenous glucocorticoids can decrease postoperative nausea and vomiting and pain in total joint arthroplasty: a meta-analysis and trial sequence analysis. Medicine (Baltimore). 2017;96(13):e6382.

37. François B, Bellissant E, Gissot V, et al. 12-h pretreatment with methylprednisolone versus placebo for prevention of postextubation laryngeal oedema: a randomised double-blind trial. Lancet. 2007;369 (9567):1083-1089.

38. Gribsholt SB, Svensson E, Thomsen RW, Richelsen B, Sørensen HT. Preoperative glucocorticoid use and risk of postoperative bleeding and infection after gastric bypass surgery for the treatment of obesity. Surg Obes Relat Dis. 2015;11(6):1212-1217.

39. Reinau D, Schwenkglenks M, Früh M, Signorell A, Blozik E, Meier CR. Glucocorticoids and the risk of peptic ulcer bleeding: case-control analysis based on Swiss claims data. Drug Safety. 2018;41(7):725-730.

40. Wang Z, Chen Z, Zhang L, et al. Status of hypertension in China: results from the China hypertension survey, 2012-2015. Circulation. 2018;137(22):2344-2356.

41. Phillips W, Piller LB, Williamson JD, et al. Risk of hospitalized gastrointestinal bleeding in persons randomized to diuretic, ACE-inhibitor, or calcium-channel blocker in ALLHAT. $J$ Clin Hypertens (Greenwich). 2013;15(11):825-832.

42. Espinosa A, Ripollés-Melchor J, Casans-Francés R, et al. Perioperative use of clevidipine: a systematic review and meta-analysis. PLoS One. 2016;11(3):e0150625.

43. Hollmann C, Fernandes NL, Biccard BM. A systematic review of outcomes associated with withholding or continuing angiotensin-converting enzyme inhibitors and angiotensin receptor blockers before noncardiac surgery. Anesth Analg. 2018;127(3):678-687.

44. Han J, Liang Y, Shao H, et al. Analysis of inappropriate medication in elderly inpatients evaluated by beers criteria and STOPP/START criteria. China Pharmacist. 2019;22(1):116-119.

45. Masnoon N, Shakib S, Kalisch-Ellett L, Caughey GE. What is polypharmacy? A systematic review of definitions. BMC Geriatr. 2017;17 (1):230. 
46. Nobili A, Licata G, Salerno F, et al. Polypharmacy, length of hospital stay, and in-hospital mortality among elderly patients in internal medicine wards. The REPOSI study. Eur J Clin Pharmacol. 2011;67(5):507-519.

47. McDonald SR, Heflin MT, Whitson HE, et al. Association of integrated care coordination with postsurgical outcomes in high-risk older adults: the Perioperative Optimization of Senior Health (POSH) initiative. JAMA Surg. 2018;153(5):454-462.
48. Ljungqvist O, Scott M, Fearon KC. Enhanced recovery after surgery: a review. JAMA Surg. 2017;152(3):292-298.

\section{Publish your work in this journal}

Clinical Interventions in Aging is an international, peer-reviewed journal focusing on evidence-based reports on the value or lack thereof of treatments intended to prevent or delay the onset of maladaptive correlates of aging in human beings. This journal is indexed on PubMed Central, MedLine, CAS, Scopus and the Elsevie
Bibliographic databases. The manuscript management system is completely online and includes a very quick and fair peer-review system, which is all easy to use. Visit http://www.dovepress.com/ testimonials.php to read real quotes from published authors.

Submit your manuscript here: https://www.dovepress.com/clinical-interventions-in-aging-journal 